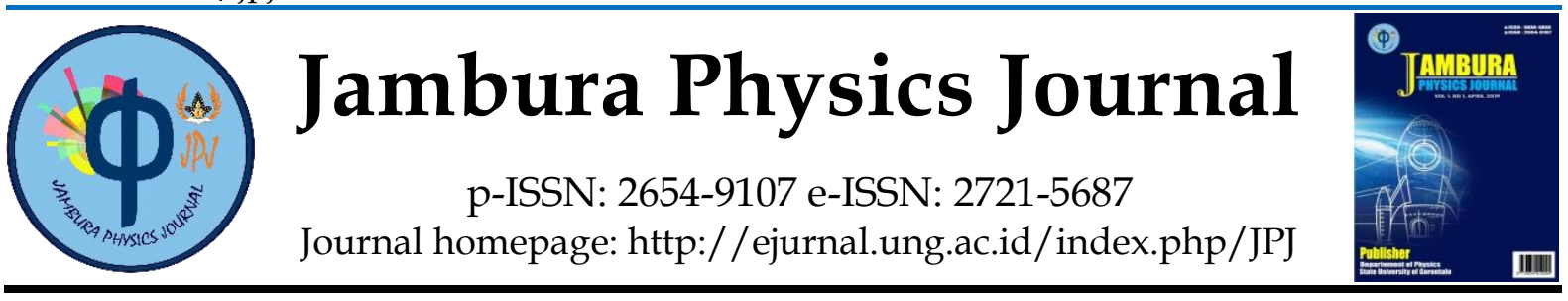

\title{
PENGEMBANGAN LKPD BERBASIS PROBLEM SOLVING BERBANTUAN SOFTWARE TRACKER UNTUK MENINGKATKAN KETERAMPILAN PEMECAHAN MASALAH DI SMA
}

\author{
Emi Risa ${ }^{*}$, Lukman Hakim², Dwi Ratnaningdyah ${ }^{3}$, Rita Sulistyowati ${ }^{4}$ \\ 1,2,3,4 Program Studi Pendidikan Fisika' FKIP, Universitas PGRI Palembang Jl. Jend. A, Yani Lrg. Gotong \\ Royong 9/10 Ulu Palembang \\ Email: emirisaay0703@gmail.com
}

Received: 17 December 2020. Accepted: 27 April 2021. Published: 30 April 2021

\section{ARTICLE INFO}

\author{
Keywords: \\ Problem-solving; \\ Worksheet development; \\ Software tracker
}

How to cite:

Risa, M., Hakim, L., Ratnaningdyah, D \& Sulistiyowati, R. (2021).

Pengembangan LKPD

Berbasis Problem Solving Berbantuan Software

Tracker untuk

Maningkatkan

Keterampilan Pemecahan Masalah Di SMA. Jambura Physics Journal, 3(1), 42-53.

DOI:

https://doi.org/10.34312

/jpj.v3i1.8705

\begin{abstract}
Development research has been carried out to produce student worksheets (LKPD) based on problem-solving assisted by tracker software that is valid, practical, and has the potential effect of improving problem-solving skills. This research is development research (R\&D) that uses the Rowntree model which consists of the planning stage, the development stage, and the evaluation stage, which includes self-evaluation, expert review, one-to-one evaluation, small group evaluation, and field test. The subjects in this study were students of class X SMA in Palembang. Based on the expert review stage, the validity of the LKPD based on problemsolving assisted by tracker software in terms of the feasibility of the material, language, and learning design obtained an average value of $90 \%$ with the very valid category. The one-to-one stage obtained an average value of $87 \%$ in the very practical category. The small group stage obtained an average score of $86 \%$ in the very practical category. In the field test stage, $91 \%$ of students completed the physics questions and the post-test results showed an increase of 50 when compared to the pre-test results.
\end{abstract}


Risa, E. et al. / Jambura Physics Journal (2021) Vol. 3 (1): 42-53

\section{Pendahuluan}

Fisika merupakan salah satu mata pelajaran yang ada di Sekolah Menegah Atas (SMA). Fisika merupakan ilmu sains yang mempelajari tentang pembentukan alam yang menyangkut fenomena alam dan seluruh interaksi yang ada di dalam alam semesta, di dalam proses pembelajaran fisika perserta didik dilibatkan langsung dalam membangun suatu model pembelajaran yang telah ditentukan oleh pendidik agar dapat membantu peseta didik untuk memahami apa hubungan dan perbedaan antara konsep-konsep fisika dalam fenomena alam semesta (Ratnaningdyah, 2016).

Sebagai ilmu yang mempelajari fenomena alam, fisika juga memberikan pelajaran yang baik kepada manusia untuk hidup tentram dan berhubungan baik berdasarkan hukum alam. Mata pelajaran fisika di harapkan dapat menumbuhkan kemampuan berpikir untuk memecahkan permasalahan dalam kehidupan seharihari sehingga perlu diajarkan secara optimal (Nurliawati et al., 2017).

Studi pendahuluan dilakukan di kelas X salah satu SMA di Palembang dengan metode wawancara. Wawancara dilakukan dengan guru mata pelajaran fisika dan peserta didik, serta mengamati kegiatan belajar mengajar di sekolah. Setelah melakukan studi pendahuluan didapat bahwa sebagian besar perserta didik merasa bahan ajar yang biasa digunakan kurang menarik, kurang inovatif, kurang variatif, dan tidak sesuai dengan tingkat kebutuhan peserta didik (Nurliawati et al., 2017). Peserta didik beranggapan bahwa pelajaran fisika adalah pelajaran yang sulit dan rumit. Menurut mereka pelajaran fisika selalu menggunakan rumus, semua masalah atau soal yang ada pada pelajaran fisika harus diselesaikan dengan rumus, oleh karena itu peserta didik menjadi tidak menyukai pelajaran fisika, terlebih para guru di sekolah kebanyakan menjelaskan materi yang ada di buku panduan secara singkat dan tidak melibatkan langsung peserta didik dalam proses belajar. Hal tersebutlah yang membuat peserta didik tidak memahami materi yang diberikan oleh guru sehingga kemampuan pemecahan masalah peserta didik tidak terlatih dan hasil belajar mereka menjadi rendah.

Kemampuan pemecahan masalah adalah kemampuan berpikir tingkat tinggi pada aspek pengetahuan (Venisari et al., 2015). Masalah yang sering terjadi pada kemampuan pemecahan masalah ialah peserta didik tidak memahami inti dari permasalahan yang diberikan, peserta didik terkadang diberikan tugas tanpa ada penjelasan, peserta didik kesulitan menyelesaikan masalah yang berbeda dengan contoh yang diberikan (Darti et al., 2015).

Ada banyak sekali bahan ajar dan sumber belajar yang dapat digunakan dan dimanfaatkan untuk meningkatkan keterampilan pemecahan masalah peserta didik, salah satunya yaitu penggunaan bahan ajar seperti LKPD. Lembar kerja peserta didik (LKPD) merupakan lembaran-lembaran yang berisi tugas yang harus dikerjakan oleh perserta didik. Lembar kegiatan biasanya berupa petunjuk atau lagkah-langkah untuk menyelesaikan suatu tugas. Langkah-langkah yang digunakan harus dapat melatih perserta didik dalam menyelesaikan masalah. Proses pemecahan masalah memberikan kesempatan peserta didik berperan aktif dalam mempelajari, mencari, dan menemukan sendiri informasi untuk diolah menjadi konsep, prinsip, teori, atau kesimpulan (Laili et al., 2019).

LKPD dapat dikembangkan dengan berbagai macam inovasi yang unik dan menarik untuk dipelajari oleh peserta didik agar konsep-konsep fisika cepat 
Risa, E. et al./ Jambura Physics Journal (2021) Vol. 3 (1): $42-53$

dipahami. Salah satunya dengan mengkombinasikan LKPD dengan model pembelajaran problem solving dengan berbantuan software tracker. Model pembelajaran problem solving berbantuan software tracker diharapkan mampu meningkatkan keterampilan pemecahan masalah peserta didik, karena dalam model pembelajaran problem solving memberikan prosedur pemecahan masalah dengan langkah-langkah dengan memfokuskan permasalahan, menjabarkan aspek fisika, rencana pemecahan masalah, menjalankan rencana, dan mengevaluasi jawaban (Nurliawati et al., 2017).

Menurut Aflaha (2017), problem solving merupakan metode pemecahan masalah atau suatu cara menyajikan pelajaran dengan mendorong perserta didik untuk mencari dan menemukan solusi penyelesaian masalah atau persoalan. Dalam menyelesaikan masalah atau persoalan pada materi gerak parabola, peserta didik akan dibantu dengan menggunakan software tracker. Software tracker adalah sebuah perangkat lunak berbasis open source Java frame work yang berfungsi untuk memodelkan dan menganalisis video (Fitriyanto \& Sucahyo, 2016).

Kesulitan dalam menganalisis gerak benda pada saat praktikum yaitu sulit menentukan posisi benda, grafik, dan penentuan waktu yang kurang tepat saat pengambilan data. Dalam hal ini software tracker dapat digunakan untuk membantu peserta didik menganalisis gerak sebuah benda yang ada dalam video dengan cara membuat jejak yang mengikuti gerak benda untuk menghasilkan posisi benda, grafik dan waktu yang tepat. Alasan inilah yang mendorong peneliti untuk melakukan pengembangan LKPD berbasis problem solving berbantuan software tracker pada materi gerak parabola untuk meningkatkan keterampilan pemecahan masalah peserta didik kelas X IPA SMA di Palembang.

Adapun tujuan dalam penelitian ini yaitu menghasilkan LKPD berbasis problem solving berbantuan software tracker yang valid, praktis dan memiliki efek potensial untuk meningkatkan keterampilan pemecahan masalah fisika peserta didik kelas $\mathrm{X}$ salah satu SMA di Palembang. Tujuan penelitian ini didukung oleh penelitian (Agustina \& Adesti, 2019) dan (Ubaidillah, 2016).

\section{Metode}

\subsection{Jenis dan subjek penelitian}

Penelitian ini digolongkan kedalam penelitian pengembangan (Development and Research) untuk menghasilkan bahan ajar berupa LKPD berbasis problem solvingberbantuan software tracker. Dalam penelitian ini, peneliti menggunakan model pengembangan Rowntree. Model pengembangan ini terdiri dari tiga tahapan yaitu perencanaan, pengembangan dan evaluasi. Evaluasi yang digunakan adalah model evaluasi formatif Tessmer yang terdiri dari lima tahap yaitu evaluasi diri, evaluasi ahli, one-to-one, small group, dan field test (Wahyuni \& Lia, 2020).

Subjek penelitian ini adalah peserta didik kelas X salah satu SMA di Palembang.

\subsection{Instrumen penelitian}

Instrumen yang digunakan dalam penelitian ini antara lain : (1) wawancara pada saat peneliti melakukan studi pendahuluan untuk mengetahui permasalahan yang harus diteliti; (2) walkthrough, untuk mengetahui gambaran mengenai kevalidan produk yang dikembangkan; (3) angket, untuk mengetahui pendapat peserta didik 
Risa, E. et al. / Jambura Physics Journal (2021) Vol. 3 (1): 42-53

terhadap produk yang dikembangkan; (4) tes untuk mengukur kemampuan peserta didik.

\subsection{Teknik analisis data}

Data yang diperoleh dalam penelitian ini antara lain: (1) data analisis kebutuhan peserta didik; (2) data validasi penilaian produk oleh ahli (materi, bahasa, dan desain pembelajaran); (3) data respon peserta didik terhadap penilaian produk; (4) hasil tes peserta didik.

Untuk menghitung rata-rata skor yang diperoleh tahap evaluasi ahli, tahap oneto-one dan tahap small group dihitung dengan menggunakan rumus pada persamaan 1 berikut:

$$
\text { Nilai Validitas }=\frac{\text { jumlah skor yang diperoleh }}{\text { jumlah skor maksimal }} \times 100 \%
$$

(Wirdani et al., 2019)

Untuk menghitung rata-rata skor yang diperoleh tahap one to one, dan small group dihitung rata-ratanya dengan menggunakan rumus pada persamaan 2 berikut:

Nilai Praktikalitas $=\frac{\text { jumlah skor yang diperoleh }}{\text { jumlah skor maksimal }} \times 100 \%$

Data yang diperoleh pada tahap evaluasi ahli, one-to-one, dan small group dianalisis dengan skala likert untuk dengan lima pilihan jawaban, yaitu sangat kurang (1), kurang (2), cukup (3), baik (4), dan sangat baik (5).

Uji coba lapangan (field test) dilakukan pada kelas yang sebenarnya. Hasil field test digunakan untuk mengetahui efek potensial terhadap peningkatan keterampilan pemecahan masalah Fisika peserta didik. Peningkatan keterampilan pemecahan masalah peserta didik dilihat dari nilai $N$-gain hasil pretest dan posttest dengan persamaan 3 berikut:

$$
N-\text { gain }=\frac{\text { skor posttest }- \text { skor pretest }}{\text { skor maksimum }- \text { skor pretest }}
$$

Tabel 1. Kriteria Interprestasi N-gain

\begin{tabular}{ll}
\hline$N-$ Gain & Kriteria Interprestasi \\
\hline$N-$ gain $>0,7$ & Tinggi \\
$0,7>N-$ gain $\geq 0,3$ & Sedang \\
$N-$ gain $<0,3$ & Rendah \\
\hline & Sumber: (Novita et al., 2016)
\end{tabular}

\section{Hasil dan Pembahasan}

\subsection{Hasil}

\section{a. Tahap perencanaan}

Tahap perencanaan terdiri atas analisis kebutuhan dan merumuskan tujuan pembelajaran. Analisis kebutuhan dilakukan dengan melakukan wawancara kepada peserta didik kelas X SMA. Hasil wawancara informal kepada beberapa peserta didik, menunjukkan bahwa: (1) Fisika merupakan pembelajaran yang sulit dan 
Risa, E. et al./ Jambura Physics Journal (2021) Vol. 3 (1): $42-53$

membosankan bagi peserta didik, karena menurut mereka fisika itu kurang menarik dan hanya membahas rumus-rumus saja; (2) Pembelajaran fisika hanya menjelaskan tentang konsep dan kemudian penyelesaian soal. Guru kurang memanfaatkan media pembelajaran dan belum mengaitkan materi dengan lingkungan sekitar peserta didik, hanya melalui persepsi saja; (3) Bahan ajar yang digunakan yaitu buku paket dari penerbit. Berdasarkan dari data yang didapat pada wawancara analisis kebutuhan, bahan ajar yang diperlukan peserta didik adalah bahan ajar yang menarik berupa LKPD yang mengaitkan materi dengan kehidupan sehari-hari serta terdapat praktikum. Dari hasil analisis kebutuhan, materi yang dibahas pada penelitian ini yaitu Gerak Parabola. Produk yang dikembangkan yaitu LKPD berbasis problem solving berbantuan software tracker.

\section{b. Tahap pengembangan}

Pengembangan topik

Tahap ini dilakukan dengan membuat langkah-langkah untuk membuat LKPD yang sesuai dengan silabus pembelajaran, yaitu pada materi pokok bahasan gerak parabola dan pemanfaatan gerak parabola dalam kehidupan sehari-hari. Selanjutnya, peneliti menyusun langkah-langkah dalam pembelajaran problem solving yaitu: (1) memfokuskan permasalahan (comprehend the problem); (2) menjabarkan aspek fisikanya (represent the problem in formal term); (3) rencana pemecahan (plan a solution); (4) menjalankan rencana (execute the plan); (5) mengevaluasi jawabannya (evaluate the answer).

\section{Penyusunan draft}

Peneliti selanjutnya melakukan penyusunan draf dengan menentukan komponen-komponen yang akan dituliskan dalam prototype LKPD berbasis problem solving berbantuan software tracker pada materi gerak parabola yakni sebagai berikut: (1) Cover LKPD berbasis problem solving berbantuan software tracker, memuat materi, nama penulis, dan judul LKPD; (2) Kata pengantar dan daftar isi. (3) Standar isi yang terdiri dari Kompetensi Inti dan Kompetensi Dasar; (4) Tujuan Pembelajaran; (5) Petunjuk Kegiatan; (6) Peta konsep yang memuat konsep materi gerak parabola yang disusun berdasarkan isi LKPD; (7) Pada bagian awal berisikan tentang materi gerak parabola dan langkah penggunaan software tracker sebelum masuk lembar kerja peserta didik (LKPD); (8) Lembar praktikum, memuat percobaan yang harus dilakukan oleh peserta didik; (9) Evaluasi, memuat soal-soal yang harus dikerjakan peserta didik setelah melakukan percobaan; (10) Daftar pustaka, memuat sejumlah referensi yang digunakan peneliti sebagai acuan dalam membuat LKPD.

\section{Produksi prototype}

Selanjutnya hasil penyusunan draf yang telah dilakukan, peneliti memulai produksi prototype 1 LKPD berbasis problem solving berbantuan software tracker dengan terlebih dahulu merancang format tampilan halaman prototype 1 LKPD. Format kertas yang digunakan adalah portrait dengan ukuran kertas A4 dan jenis huruf yang digunakan bervariasi. Format halaman ini digunakan peneliti untuk menulis dan menyususun komponen-komponen yang sudah disebutkan sebelumnya dengan menambahkan gambar, bingkai, maupun kolom pemberitahuan yang diatur dan disesuaikan dengan teks sehingga tampilan setiap halaman tersusun rapi dan menarik. 
Risa, E. et al. / Jambura Physics Journal (2021) Vol. 3 (1): 42-53

Gambar 1 berikut ini menunjukkan beberapa tampilan produk LKPD yang telah dikembangkan:
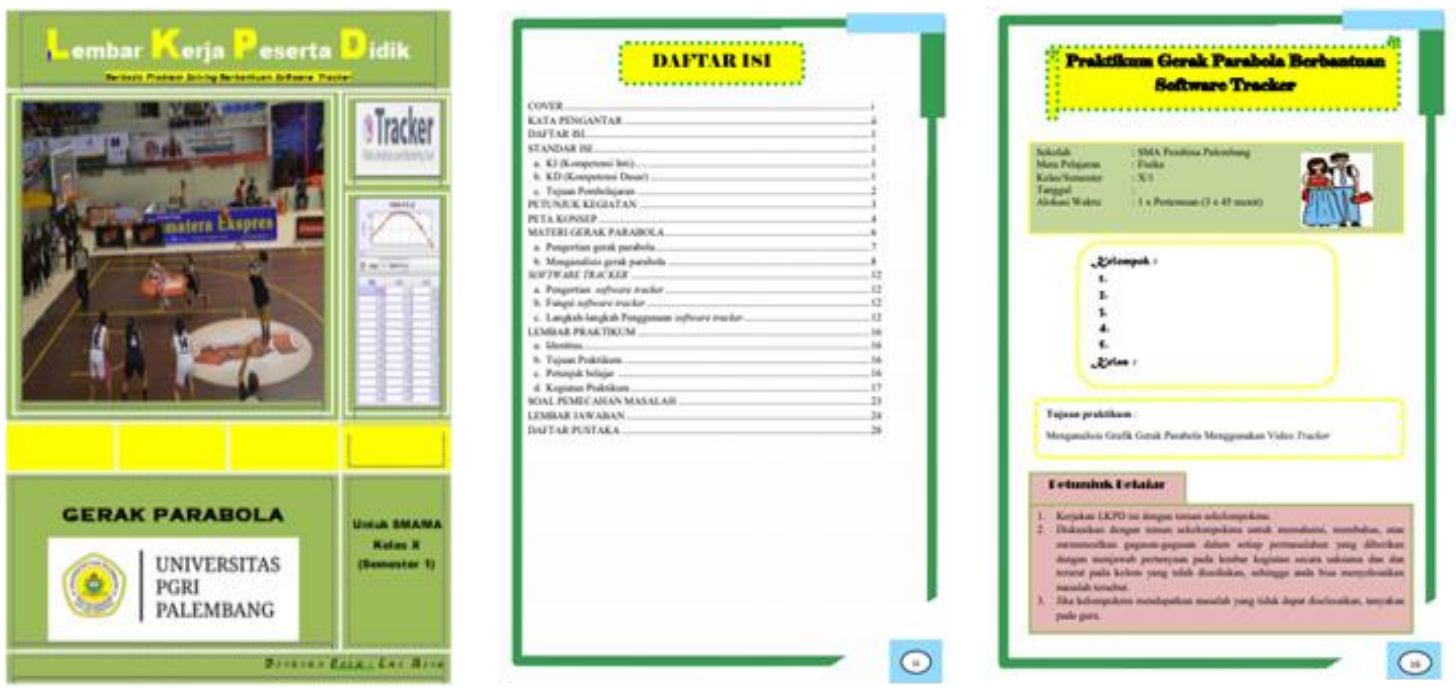

Gambar 1. Beberapa Tampilan LKPD Berbasis Problem Solving Berbantuan Software Tracker

\section{c. Tahap evaluasi}

\section{Expert Review}

Tahap expert review dievaluasi dan divalidasi oleh ahli fisika yang terdiri dari tiga validator untuk menilai apek materi, aspek bahasa, dan aspek desain pembelajaran. Rata-rata hasil validasi oleh para ahli untuk menilai ketiga aspek tersebut dapat dilihat pada tabel 2.

Tabel 2. Rata-rata Nilai Validasi Oleh Para Ahli

\begin{tabular}{|c|c|c|c|c|c|}
\hline \multirow[b]{2}{*}{ No. } & \multirow[b]{2}{*}{ Aspek yang Dinilai } & \multicolumn{3}{|c|}{ Hasil Penilaian Validator } & \multirow{2}{*}{$\begin{array}{c}\text { Rata-Rata Hasil } \\
\text { Penilaian } \\
\text { Validator }\end{array}$} \\
\hline & & Validator I & Validator II & Validator III & \\
\hline 1. & Materi & $85 \%$ & $96 \%$ & $89 \%$ & $90 \%$ \\
\hline 2. & Bahasa & $93 \%$ & $86 \%$ & $83 \%$ & $87 \%$ \\
\hline 3. & $\begin{array}{l}\text { Desain Pembelajaran } \\
\text { Problem Solving }\end{array}$ & $85 \%$ & $90 \%$ & $100 \%$ & $91 \%$ \\
\hline \multicolumn{2}{|c|}{ Kategori } & \multicolumn{3}{|c|}{ Sangat Valid } & $90 \%$ \\
\hline
\end{tabular}

Berdasarkan data tersebut didapatkan bahwa rata-rata nilai dari ketiga validator untuk aspek materi, bahasa, dan desain pembelajaran memperoleh nilai rata-rata sebesar 90\% dengan kategori sangat valid. Prototype 1 dinyatakan sangat valid, namun para pakar validator tetap memberikan saran dan masukan untuk memperbaiki LKPD berbasis problem solving berbantuan software tracker yang dikembangkan. Berikut beberapa saran dari validator yaitu: (1) Validator I, tambahkan daftar pustaka dan perbaiki bahasa penulisan yang masih terdapat typo di petunjuk penggunaan LKPD; (2) Validator II, perbaiki urutan pada tujuan pembelajaran dan tambahkan prosedur percobaan; (3) Validator III, gambar perlu diperbesar dan spasi harus disesuaikan. 
One to one evaluation

Pelaksanaan one-to-one evaluation dilakukan dengan membimbing ketiga peserta didik untuk mempelajari LKPD berbasis problem solving berbantuan software trackerkemudian di akhir pembelajaran peserta didik diminta untuk mengisi lembar angket untuk mengetahui tanggapan mereka terhadap prototype 1 yang telah digunakan. Rata-rata hasil penilaian peserta didik tahap one to one dapat dilihat pada Gambar 2.

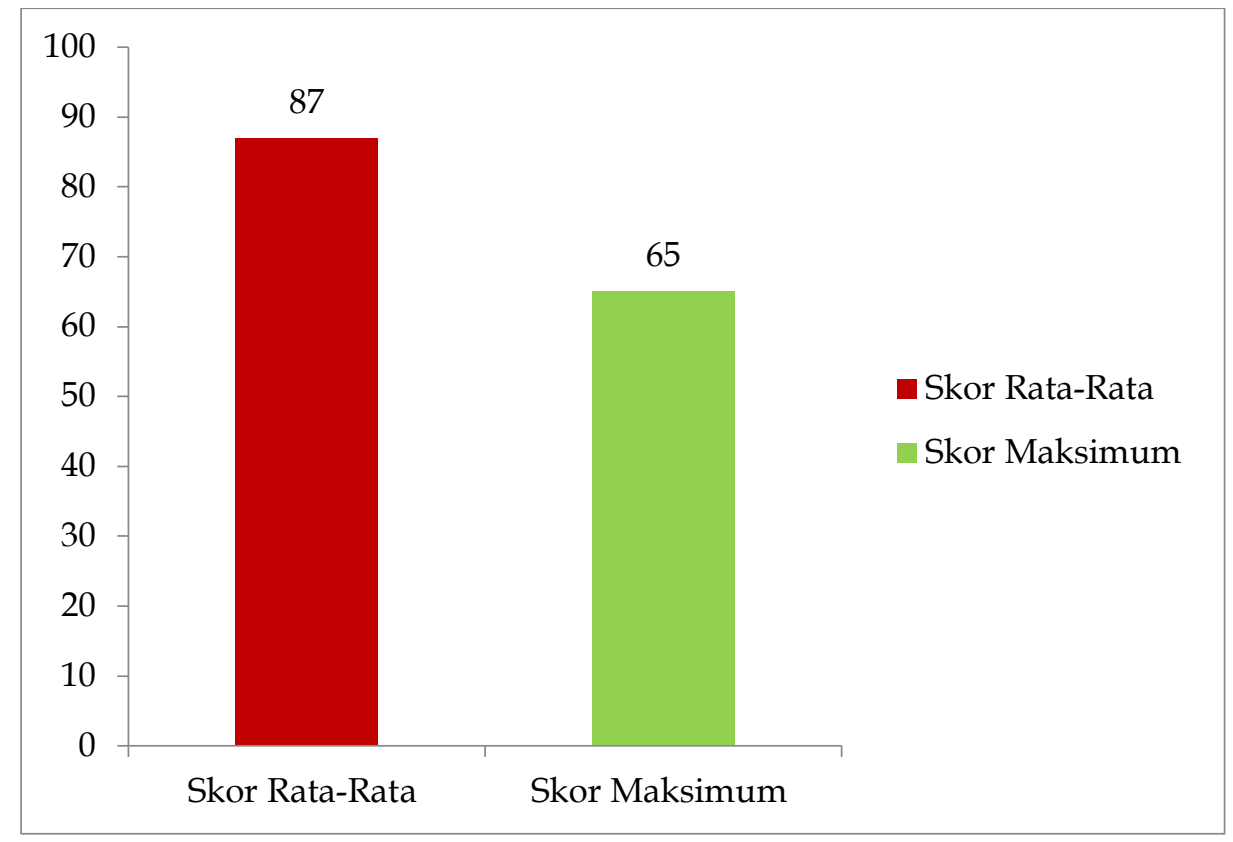

Gambar 2. Nilai Rata-Rata Penilaian Peserta Didik Tahap One to one

Berdasarkan data tersebut didapatkan bahwa rata-rata penilaian angket tanggapan peserta didik yaitu 87\%. Artinya LKPD berbasis problem solving berbantuan software tracker yang telah dinilai oleh peserta didik, menunjukkan bahwa LKPD berbasis problem solving berbantuan software tracker memenuhi kategori sangat praktis.

Small group evaluation

Tahap ini hampir sama dengan one-to-one evaluation, bedanya peneliti mengujicobakan prototype 2 mempelajari LKPD berbasis problem solving berbantuan software trackerkepada 8 orang peserta didik yang dibagi menjadi 2 kelompok. Setiap kelompok dipersilahkan untuk membaca, mempelajari maupun berdiskusi mengenai isi prototype 2 LKPD dengan tetap mendapat arahan dari peneliti. Selanjutnya di akhir pembelajaran, peserta didik diminta untuk mengisi lembar angket tanggapan mereka terhadap prototype 2 yang sudah digunakan. Rata-rata hasil penilaian peserta didik tahap small group dapat dilihat pada Gambar 3.

Berdasarkan data tersebut didapatkan bahwa rata-rata penilaian angket tanggapan peserta didik yaitu $\mathbf{8 6 \%}$. Artinya LKPD berbasis problem solving berbantuan software tracker yang telah dinilai oleh peserta didik, menunjukkan bahwa LKPD berbasis problem solving berbantuan software tracker memenuhi kategori sangat praktis. 


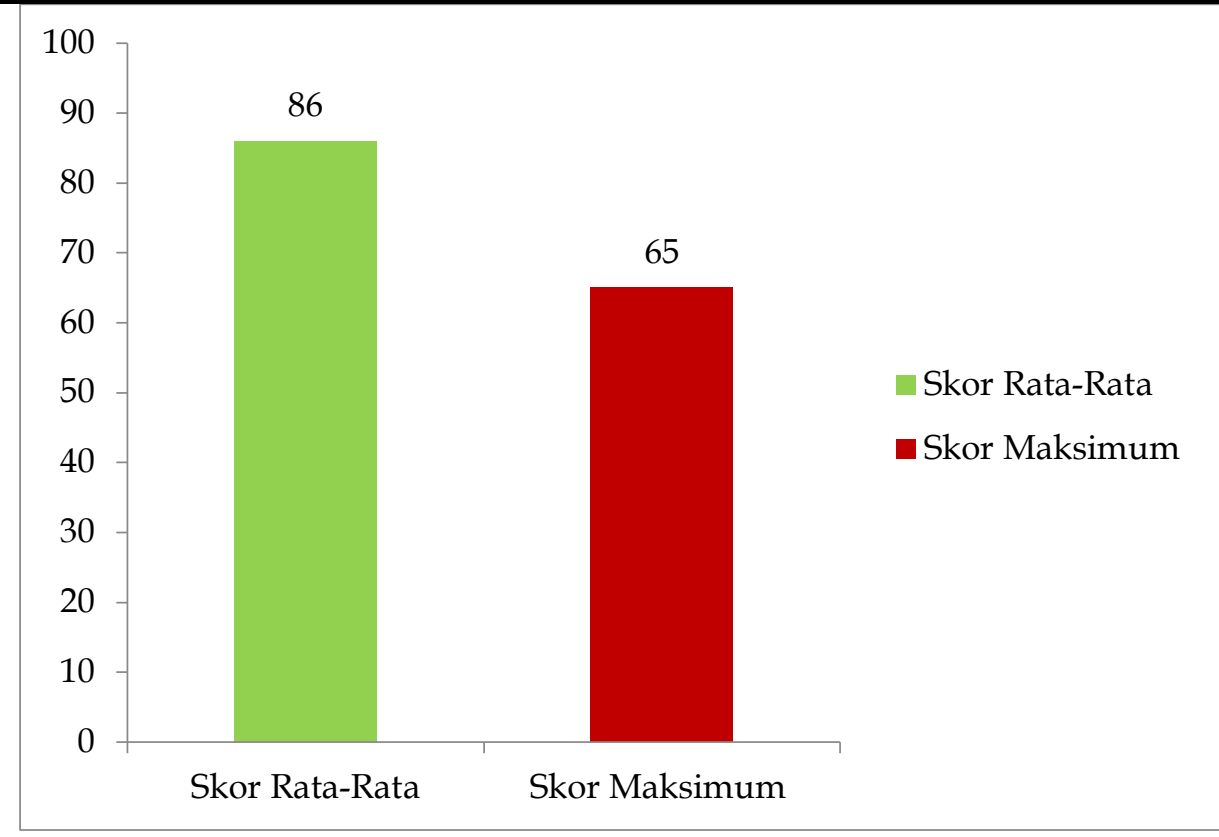

Gambar 3. Nilai Rata-Rata Penilaian Peserta Didik Tahap Small Group

Field test evaluation

Prototype 3 uji coba pada tahap Field test dengan subjek penelitian berjumlah 22 peserta didik kelas X IPA 2 SMA di Palembang. Tahap ini bertujuan untuk mengetahui efek potensial terhadap peningkatan keterampilan pemecahan masalah Fisika peserta didik. Adapun hasil uji coba lapangan peserta didik pada saat mengerjakan pre-test dan post-test dapat dilihat pada gambar 4 berikut.

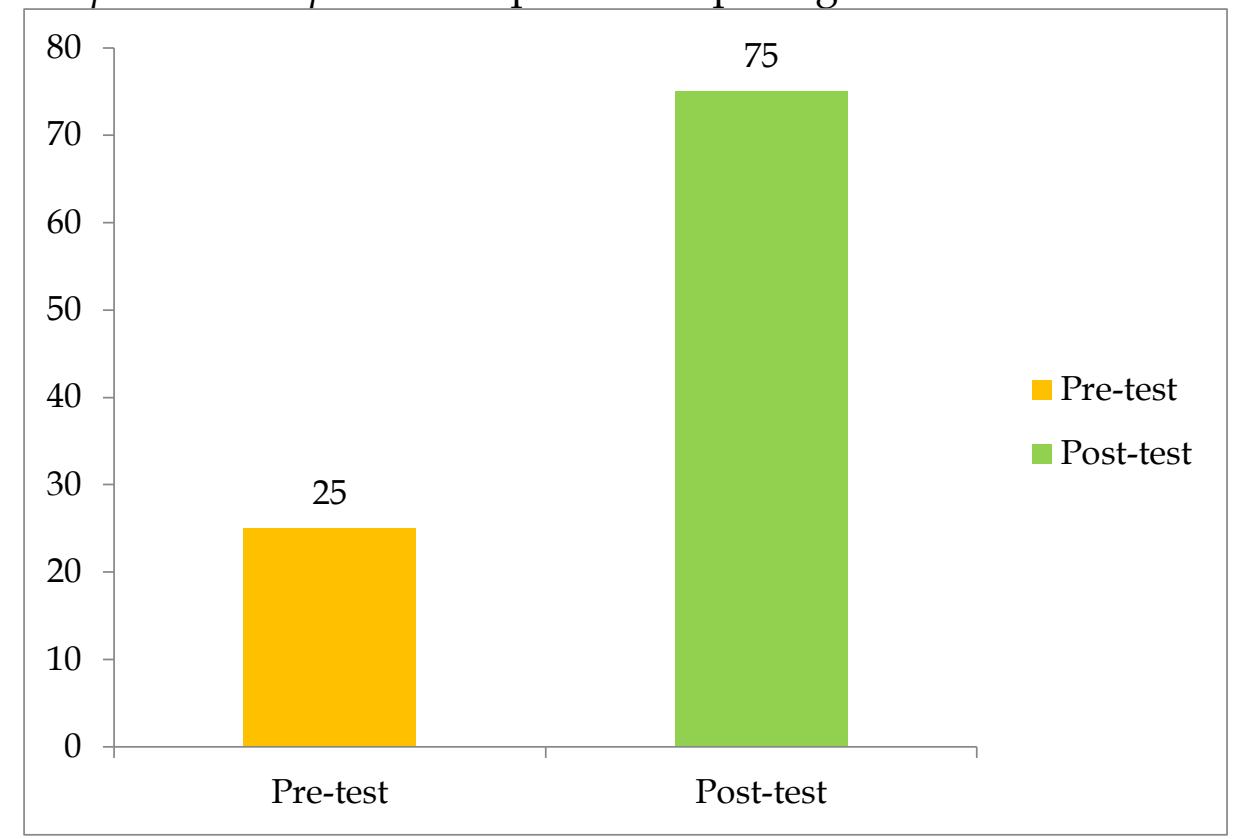

Gambar 4. Nilai Rata-rat Hasil Field Test Peningkatan Keterampilan Pemecahan Masalah 
Risa, E. et al./ Jambura Physics Journal (2021) Vol. 3 (1): $42-53$

Berdasarkan gambar 4 nampak bahwa pada saat pre-test diperoleh nilai ratarata sebesar 25 dan saat post-test diperoleh nilai rata-rata sebesar 75 Dengan demikian terjadi peningkatan sebesar 50 pada saat pembelajaran menggunakan LKPD berbasis problem solving berbantuan software tracker. Dari hasil $N$-gain yang diperoleh peserta didik menunjukkan bahwa persentase uji coba lapangan yaitu 36\% peserta didik termasuk dalam kategori $N$-gain tinggi, 63\% peserta didik termasuk dalam kategori $N$-gain sedang dan $\mathbf{0 \%}$ peserta didik termasuk dalam kategori $N$-gain rendah.

Dari analisis yang telah dilakukan pada tahap field test diketahui bahwa sebanyak 91,30\% peserta didik kelas X IPA 2 mencapai nilai KKM diatas 65 dikatakan "Tuntas". Hal ini menunjukan bahwa LKPD berbasis problem solving berbantuan software tracker dikategorikan valid, praktis, dan efektif digunakan dalam pembelajaran Fisika kelas X IPA di salah satu SMA di Palembang.

\subsection{Pembahasan}

Penelitian ini bertujuan untuk mengahasilkan LKPD berbasis problem solving berbantuan software tracker untuk kelas X SMA yang valid, praktis, dan efektif. Penelitian ini dilakukan dengan mengacu pada model pengembangan Rowntree, terdiri dari tahap perencanaan, pengembangan, dan evaluasi yang memodifikasi pada teknik evaluasi Tessmer yang terdiri dari evaluasi diri (self evaluation), uji ahli (expert review), uji satu-satu (one-to-one evalualiton), uji kelompok kecil (small group evaluation), dan uji coba lapangan (field test).

Tahap perencanaan terdiri atas analisis kebutuhan dan merumuskan tujuan pembelajaran. Analisis kebutuhan dilakukan dengan wawancara kepada guru mata pelajaran fisika dan beberapa peserta didik kelas X salah satu SMA di Palembang mengenai bahan ajar yang digunakan dan proses pembelajaran yang mereka lakukan. Tahap pengembangan yaitu terdiri dari pengembangan topik, penyusunan draf dan produksi prototype. Pengembangan topik peneliti membuat garis besar isi lembar kerja peserta didik (LKPD) dengan mengumpulkan referensi yang akan digunakan dalam proses pembentukan LKPD. Peneliti menggunakan tiga buah buku dan beberapa sumber dari internet yang dijadikan sebagai acuan dalam pembentukan LKPD. Penelitian yang juga melakukan tahap perencanaan yaitu (Aflaha, 2017) (Sudirman \& Taufiq, 2018).

Prototype 1 dikembangkan dari hasil self evaluation yang dikonsultasi dengan pembimbing, sehingga didapat beberapa saran perbaikan dapat dilihat pada tabel 3 .

Tabel 3. Saran Perbaikan Dosen Pembimbing

\begin{tabular}{|c|c|}
\hline No. & Saran Perbaikan \\
\hline 1. & $\begin{array}{l}\text { Perbaiki cover. Gambar cover harus konteks yang mencerminkan isi materi } \\
\text { untuk menarik minat belajar peserta didik }\end{array}$ \\
\hline 2. & $\begin{array}{l}\text { Perbaiki peta konsep. Peta konsep harus sesuai dengan susunan dan isi materi } \\
\text { yang di LKPD }\end{array}$ \\
\hline 3. & $\begin{array}{l}\text { Perbaiki petunjuk penggunaan. Bahasa penulisan pada petunjuk penggunaan } \\
\text { LKPD dipersejalas untuk mempermudah peserta didik menggunakan LKPD }\end{array}$ \\
\hline 4. & $\begin{array}{l}\text { Perbaiki tujuan pembelajaran. Tujuan pembelajaran disesuaikan dengan } \\
\text { indikator yang ingin dicapai }\end{array}$ \\
\hline 5. & $\begin{array}{l}\text { Tambahkan soal pemecahan masalah untuk melihat peningkatan keterampilan } \\
\text { pemecahan masalah peserta didik }\end{array}$ \\
\hline
\end{tabular}


Risa, E. et al. / Jambura Physics Journal (2021) Vol. 3 (1): 42-53

Berdasarkan saran ini peneliti melakukan perbaikan pada tahap prototype 1 yang kemudian dikonsultasikan kembali dengan pembimbing hingga layak untuk divalidasi sekaligus penyusunan perangkat evaluasi. Setelah prototype 1 dan perangkat evaluasi dinyatakan layak dan disetujui oleh pembimbing, selanjutnya peneliti melakukan tahap expert review.

Selanjutnya tahap evaluasi dilakukan melalui beberapa langkah yaitu validasi ahli yang dilakukan oleh 3 orang validator, dari analisis tentang validitas LKPD berbasis problem solving berbantuan software tracker yang telah dinilai oleh beberapa validator, menunjukan bahwa bahan ajar berupa LKPD ini memenuhi kategori sangat valid. Kemudian dilakukan tahap one to one untuk melihat praktikalitas produk. Berdasarkan saran dari validator ahli dan komentar peserta didik tahap one to one, produk direvisi yang kemudian dihasilakan prototype 2 yang diuji cobakan pada tahap small group. Dari tahap ini, menunjukan bahwa LKPD ini memenuhi kategori sangat praktis, kemudian dihasilkan prototype 3 yang diuji cobakan pada subjek penelitian yaitu peserta didik kelas X IPA SMA di Palembang.

Tahap field test atau uji lapangan dimaksudkan untuk mengetahui efek potensial terhadap peningkatan keterampilan pemecahan masalah Fisika peserta didik. Dari hasil field test diperoleh bahwa $91 \%$ peserta didik tuntas dalam mengerjakan soal Fisika dan hasil post-test menunjukkan peningkatan sebesar 50 jika dibandingkan dengan hasil pre-test. Oleh karena itu, LKPD berbasis problem solving berbantuan software tracker yang dikembangkan memiliki efek potensial terhadap peningkatan keterampilan pemecahan masalah Fisika. Dengan demikian dapat disimpulkan bahwa LKPD berbasis problem solving berbantuan software tracker dinyatakan valid, praktis, dan memiliki efek potensial. LKPD berbasis problem solving berbantuan software tracker ini layak untuk digunakan dalam proses pembelajaran.

\section{Kesimpulan}

LKPD berbasis problem solving berbantuan software tracker yang dikembangkan dalam penelitian ini dikategorikan "sangat valid", yang tegambar dari hasil penilaian validator dimana semua validator menyatakan baik berdasarkan aspek materi, aspek bahasa, dan aspek desain pembelajaran. Adapun respon peserta didik terhadap LKPD diperoleh dengan kategori setuju, sehingga dapat dinyatakan bahwa LKPD tersebut telah layak untuk digunakan dalam proses pembelajaran Fisika. Sedangkan keterlaksanaan pembelajaran dengan menggunakan LKPD yang telah dikembang ini diperoleh dengan kategori "sangat praktis". LKPD berbasis problem solving berbantuan software tracker memiliki efek potensial terhadap peningkatan keterampilan pemecahan masalah dengan kategori sedang. Dilihat dari tes hasil belajar peserta didik yang memenuhi kategori $91,30 \%$ peserta didik mencapai nilai KKM diatas 65 dikatakan "Tuntas". Hal tersebut menunjukkan bahwa LKPD efektif digunakan pada peserta didik kelas X IPA SMA di Palembang.

\section{Referensi}

Aflaha, D. S. (2017). Pengembangan Modul Berbasis Problem Solving Pada Mata Kuliah Elektronika. Tecnoscienza, 2 (1). 
Risa, E. et al./ Jambura Physics Journal (2021) Vol. 3 (1): $42-53$

Agustina, N., \& Adesti, A. (2019). Pengembangan Modul Mata Kuliah Strategi Belajar dan Pembelajaran Pada Fkip-Universitas Baturaja. Jurnal Ilmiah Indonesia, 4 (9).

Darti, E, Y., Fuaduazmi, M., \& Budi, D. S. (2015) Pengaruh Penggunaan Laboratorium Virtual Fisika Terhadap Kemampuan Pemecahan Masalah Siswa. Jurnal Ilmiah Fisika "Lensa", III(2).

Fitriyanto, I., \& Sucahyo, I. (2016). Penerapan Software Tracker Video Analyzer pada Praktikum Kinematika Gerak. Jurnal Inovasi Pendidikan Fisika (JIPF) 5 (3), 9297.

Laili, N., Purwanto, S. E., \& Alyani, F. (2019). Pengaruh Model Penemuan Terbimbing Berbantu LKPD terhadap Kemampuan Pemahaman Konsep Matematis Siswa SMPN 6 Depok. International Journal of Humanities, Management, and Social Science , 2 (1), 14-37.

Novita, E. W., Burhan, A., \& Darlius. (2016). Pengembangan Multimedia Interaktif Modul Drill and Practice pada Mata Kuliah Pengukuran Teknik di Program Studi Pendidikan Teknik Mesin Universitas Sriwijaya. Jurnal Pendidikan Teknik Mesin, 3, 9-17.

Nurliawati, L., Mujasam, Yusuf. I., \& Widyaningsih. S.W. (2017). Lembar Kerja Perserta Didik (LKPD) berbasis Problem Solving Polya. Jurnal Pendidikan Indonesia, 6 (1).

Prastowo, Andi. 2015. Panduan Kreatif Membuat Bahan Ajar Inovatif (Menciptakan Metode Pembelajaran yang Menarik dan Menyenangkan). Yogyakarta: Diva Press.

Ratnaningdyah, D. (2016). Analisis Peningkatan Pemahaman Konsep Siswa SMA melalui Penerapan Model Pembelajaran Novick Dipadukan Dengan Strategi Cooperatif Problem Solving (CPS). Prosiding .

Sudirman, Taufiq, K., (2018). Pengembangan Modul Mata Kuliah Gelombang Berbasis Stem (Science Technology Engineering And Mathematics) Pada Program Studi Pendidikan Fisika. Jurnal Inovasi dan Pembelajaran Fisika (JIPF).

Ubaidillah, Mujib. (2016). Pengembangan LKPD Fisika Berbasis Problem Solving Untuk Meningkatkan Keterampilan Proses Sains Dan Keterampilanberpikir Tingkat Tinggi. Jurnal EduFisika, 1(2), 9-20.

Venisari,R., Gunawan., \& Sutrio. (2015). Penerapan Metode Mind Mapping pada Model Direst Instruction untuk Meningkatkan Kemampuan Pemecahan Masalah Fisika Siswa SMPN 16 Mataram. 1(3). 
Risa, E. et al. / Jambura Physics Journal (2021) Vol. 3 (1): 42-53

Wahyuni, A., Lia, L. (2020). Pengembangan Komik Fisika Berbasis Kearifan Lokal Palembang di Sekolah Menengah Atas. Jurnal Penelitian Pembelajaran Fisika, 11(1).

Wirdani, R., Lazulva, \& Octarya, Z. (2019). Desain Dan Uji Coba Lembar Kerja Peserta Didik (LKPD) Berbasis Sets (Science, Environment, Technology, And Society) Pada Materi Koloid. Jedchem (Journal Education and Chemistry), 1 (2), 56. 